\title{
THE RELATIONSHIP BETWEEN ORGANIZATIONAL IDENTIFICATION AND LIFE SATISFACTION: A STUDY ON TRAVEL AGENCIES
}

\author{
Rüya Ehtiyar ${ }^{1}$ \\ Akin Aksu' \\ Ömür Uçar $^{3}$
}

\begin{abstract}
The purpose of this study is to examine whether organizational identification has an impact on life satisfaction. Quantitative research methods were used in the study. Research findings have shown that there is a positive relationship between organizational identification and life satisfaction, and that organizational identification predicts life satisfaction.
\end{abstract}

Keywords: Organizational Identification, Life Satisfaction, Travel Agencies

\section{Introduction}

Life satisfaction is the cognitive judgement of one's overall satisfaction with his or her life or the quality of his or her life, and is measured by overall life satisfaction (Diener et al., 1985: 72) and satisfaction at vital moments. Life satisfaction shows whether an individual is content with his or her life both in general and in terms of certain life areas such as family, friends, and schools (Çivitçi and Topbaşoğlu, 2015: 15). The concept of life satisfaction, first put forward by Neugarten (1961), or better known as happiness, is one of the topics that have been the centre of humanity's attention throughout the ages.

\footnotetext{
${ }^{1}$ Associate Professor, Akdeniz University Faculty of Tourism, Antalya, TURKEY, e-mail:ehtiyar@akdeniz.edu.tr
}

\footnotetext{
${ }^{1}$ Associate Professor, Akdeniz University Faculty of Tourism, Antalya, ehtiyar@akdeniz.edu.tr

${ }^{2}$ Professor, Akdeniz University Faculty of Tourism, Antalya, aaksu@akdeniz.edu.tr

${ }^{3} \mathrm{PhD}$ Candidate, Akdeniz University Social Sciences Institute, Antalya, ucar_omur@hotmail.com
} 
${ }^{2}$ Professor, Akdeniz University Faculty of Tourism, Antalya, TURKEY, email:aaksu@akdeniz.edu.tr

${ }^{3} \mathrm{PhD}$ Candidate, Akdeniz University Social Sciences Institute, Antalya, TURKEY, e-mail: ucar_omur@hotmail.com

Life satisfaction is the condition or result obtained by comparing the expectations of a person (what one wants) with what he or she owns (what one has) (Çevik and Korkmaz, 2014: 130). Life can be defined as the whole time one spends at work and outside work (Dikmen, 1995: 117). Life satisfaction for Sumner (1966) is "A positive evaluation of the conditions of your life, a judgment that at least on balance, it measures up favourably against your standards or expectations." Andrew (1974) states life satisfaction symbolizing an overarching criterion or ultimate outcome of human experience. Satisfaction can be defined as fulfilling the expectations, needs, wishes and desires of people. (Yigit et al., 2011: 3) .Life satisfaction indicates the result of comparing one's expectations with the real situation. In general, life satisfaction includes one's whole life and the various dimensions of this life. When life satisfaction is referred, satisfaction is not considered with regard to a particular situation, but to all experiences in general (Çevik and Korkmaz, 2014: 130).

Another essential element for people to be happy and satisfied in their lives is the satisfaction they get from their work. People need to be happy and satisfied with their jobs to get the same amount of satisfaction from their lives. In this context emerges the relationship between job satisfaction and life satisfaction. Life satisfaction is defined as an individual's positive evaluation of his or her whole life in accordance with the criteria set by the individual himself or herself (Çeçen, 2008). 
When the studies on this subject are examined, it is seen that they centre on whether job satisfaction affects life satisfaction or vice versa. Iris and Barrett (1972), London, Crandall and Seals (1977), Chacko (1983), and Chisholm (1978) have revealed that job satisfaction has an impact on life satisfaction based on the assumption that work attitudes are the main factors determining behaviour outside of work. According to Orpen (1978), it can be argued that this relationship is quite the contrary based on two fundamental assumptions (Uyguç et al. 1998).

Job satisfaction and life satisfaction are considered to be two concepts that embrace, complement and give meaning to each other. Life satisfaction represents the satisfaction of an individual in all his or her life experiences. Another essential element for people to be happy and satisfied in their lives is the satisfaction they get from their jobs. People need to be happy and satisfied with their jobs to get the same amount of satisfaction from their lives. This is because one spends a significant part of his life at work and brings positive or negative emotions emerging here to his or her life, family, and friends. Similarly, one brings the positive and negative emotions experienced with his or her family or friends to the workplace. In this respect, work and life form a whole and give meaning to each other by embracing one another. As a matter of fact, in many studies, job satisfaction and life satisfaction are observed to be in an interaction (Zhao et al., 2016, Özyer et al., 2015, Şimşek and Aktaş- 2014, Akgündüz-2013, Kale- 2013, Zhao et al. 2011, Aşan and Erenler 2008, Saldamli 2008, Ghiselli et al. 2001).

Organizational identification is one of the important dynamics of business life and organizational identification has long emerged as a critical structure in the literature, with its effect on both employee satisfaction and organizational success (Ashforth and Mael, 1989: 20). The most basic idea behind the concept of organizational identification is that the employee is integrated with his or her work and thus identified with it (Turunç, 2011). In business life, people who work in their dream jobs, receive salaries to meet their basic human needs and have the means they desire are peaceful and happy because they have achieved the material and spiritual satisfaction. However, individuals who cannot work in their dream jobs and whose 
needs are not fulfilled or are ignored maintain a negative attitude. This attitude, taken in relation to business life, can affect life satisfaction over time (Karakuş, 2011: 47).

The researches about organizational identification started with Edward Tolman's study in 1943. According to him, identification is "the adherence of the individual to any group of which he feels himself a part" (Tolman, 1943: 142). Organizational identification is also defined similarly. It refers to the individual's identification with the total organization, an affective response of attachment to the organization (Efraty, Sirgy and Claiborne, 1991: 57). Cetin and Kinik (2016: 330), state that organization identification is the degree of similarity between the concepts when a member defines himself/ herself and the organization. According to Dutton and et all (1994: 239), identification occurs when a person identity himself/herself as an organization member is more distinct than alternative identities, and when the selfconcept of the person has many of the same trait he or she believes define the organization as a social group.

Organizational identification is one of the dimensions of the social identification theory which is based on people's classifying themselves and others into various social categories, such as organizational membership, religious affiliation, gender, and age cohort (Ashforth and Mael 1989: 20 as cited in Tajfel\& Turner, 1985). Social identification is defined as the perception of belonging to a group (Asforth and Mael, 1989: 21). The individual perceives himself as a real or symbolic member of the group. Thus, social identification responds the question "who am I" partially (Karabey and İşcan, 2007: 232).

There are two dimensions of organizational identification. One is group identification which means experiencing at personal level the group's successes or failures (Boroş, 2008: 3). The other one is Identification by Organization that is a form of identification based on the cognitive bases that employees feel about their organizations. There is no doubt that this cognitive situation gains advantages for organizations in respect of increasing performance and motivation of employees (Tokgöz, 2012: 44) 
As a consequence, organizational identification creates attachments to organizations for employees (Yeşiltaş, 2012: 50). Organizations often support these attachments because they affect performance outcomes, employee commitment and evaluations of the organization positively (Hoyer, 2016: 166). Moreover, a higher degree of organizational identification helps employees to do their best to fulfil their organization's best interests (Lee, and et all., 2009). Additionally, Footed (1951) asserted that organizational identification is the basis of motivation theory.

According to the written literature, organizational identification is positively associated with work attitude, individual behaviour, and outcomes (Chan, 2006), such as work motivation, task-performance, job satisfaction, perceived organizational prestige and organizational citizenship behaviours and negatively associated with turnover intentions and actual turnover (Meal and Ashforth, 1992; Abrams, Ando, \& Hinkle, 1998; Van Knippenberg, 2001; Riketta, 2005; Van Knippenberg and Sleebos, 2006; Jiang, 2010; Kesen, 2016).

These approaches, which show that there are no sharp boundaries between one's work life and private life and that these two interact with each other (Keser, 2005), make it necessary to question the impact of organizational variables on the whole life of the individual as well as the organization. Thus, the present study aims to examine the interaction between organizational identification and life satisfaction. In this context, the following research questions are asked:

1. What is the relationship between the employees' organizational identification and life satisfaction?

2. To what extent does organizational identification explain the variance in life satisfaction?

\section{RESEARCH METHOD}

The research centres on the organizational identification of employees and examines the relationship between organizational identification and life satisfaction variable. In this context, quantitative research method was adopted in order to test the 
research model and the main components of the method (sample, data collection tool and analyses) are explained below.

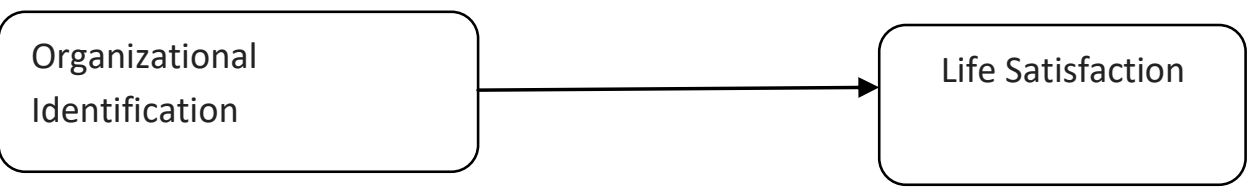

\section{Study Group}

Convenience sampling method was employed while forming the study group. Convenience sampling method was used in order to reach the people to be included in the sample so as to keep the questionnaires' rate of return high. Considering the possible data loss, the researchers decided to distribute 150 questionnaires. A total of 150 questionnaires were distributed between May and July, 2018. As a result of the analysis, a total of 124 questionnaires were considered valid to be included in the analyses due to the exclusion of the incomplete questionnaires. In the related literature, it is stated that the sample size for the analyses can be determined in proportion to the number of variables. Accordingly, the number of variables in normal distribution is recommended to be five, and a sample size that is ten times larger is suggested in other distributions (Bryman ve Cramer, 2001; as cited in Tavşanc1l, 2002). In this study, since the total number of items on the scales was 11 , it can be stated that 124 samples were above the minimum number and sufficient.

\section{Data collection tool}

In this study, survey method was used to collect data. The questionnaire is comprised of three parts. In the first part, there are questions about the demographic characteristics; the second part includes questions about organizational identification and the third part consists of questions about life satisfaction. 
Organizational Identification scale, developed by Mael and Asforth (1992), was used in order to measure the independent variable of the study, which was the concept of Organizational identification. The 5-point likert-type scale is onedimensional and consists of six items. The six-item scale of Mael and Asforth is the most commonly used scale in studies conducted on this topic. The Satisfaction with Life Scale, developed by Diener, Emmons, Larsen and Griffin (1985), was used in order to measure life satisfaction, which was the dependent variable of the study. The scale is one-dimensional and seven-point likert type. In order to test the format of the questionnaire, the comprehensibility of the items in the questionnaire and the appropriateness of the order of the questions, a pre-test was conducted with the participation of 25 people. Small changes were made to finalize the questionnaire. The reliability value of the scales used in the study was 0.92 for the Organizational Identification Scale and 0.87 for the Satisfaction with Life Scale. These values show that the reliability coefficients of both scales are high and acceptable.

\section{Analysis}

The data on the demographic characteristics of the participants were analyzed by frequency and percentage distributions. In addition, correlation and regression analyses were conducted to determine the correlation between organizational identification and life satisfaction levels.

\section{Findings and Discussion}

The findings of the study achieved as a result of performing various statistical analyses on the data obtained by survey method are presented under the heading of demographic findings; and the descriptive statistics for organizational identification and life satisfaction are given under the heading of correlation and regression analysis.

When the findings related to the demographic variables were examined, it was revealed that a total of 124 travel agency employees, $46.77 \%$ of whom were female, participated in the study. A total of $51.61 \%$ of the participants were single, and 
$55.64 \%$ of them were 31 years or older. It was also found out that $55.64 \%$ of the participants had undergraduate and graduate degrees, and $58.06 \%$ of them received tourism education. In addition, it was concluded that $46.77 \%$ of the participants had one-year and less employment in the current enterprise.

\section{Descriptive statistics}

Under this heading, the mean and standard deviation values of the scales employed in the study are presented. The mean values in Table 1 can be considered as an indicator of how positive or negative the employees, who participated in the study, were about each statement. Accordingly, the mean values calculated as low indicate a negative approach while the mean values calculated as high show a positive approach. The standard deviation values give an idea of how much the observed values differ from the mean values.

It was seen that the items that expressed life satisfaction were mostly rated over 4 (neutral) and (partially agree) by the male and female employees who participated in the study. Accordingly, it can be put forward that the employees had partially positive perceptions. According to the results of the analysis, the mean value of life satisfaction was found to vary between 4.19 and 5.16 (general average 4.55) for the female employees and between 4.09 and 4.61 (general average 4.34) for the male employees. Life satisfaction was found to be above average in both groups. When the organizational identification levels of the participants were examined, it was determined that the mean values of the items representing organizational identification were between 3.47 and 3.66 (general average 3.55) for the female employees and between 3.27 and 3.68 (general average 3.44) for the male employees. This shows that the organizational identification level of the participants was high. 
Table 1: Mean and Standard Deviation Values of the Scale Items according to Gender

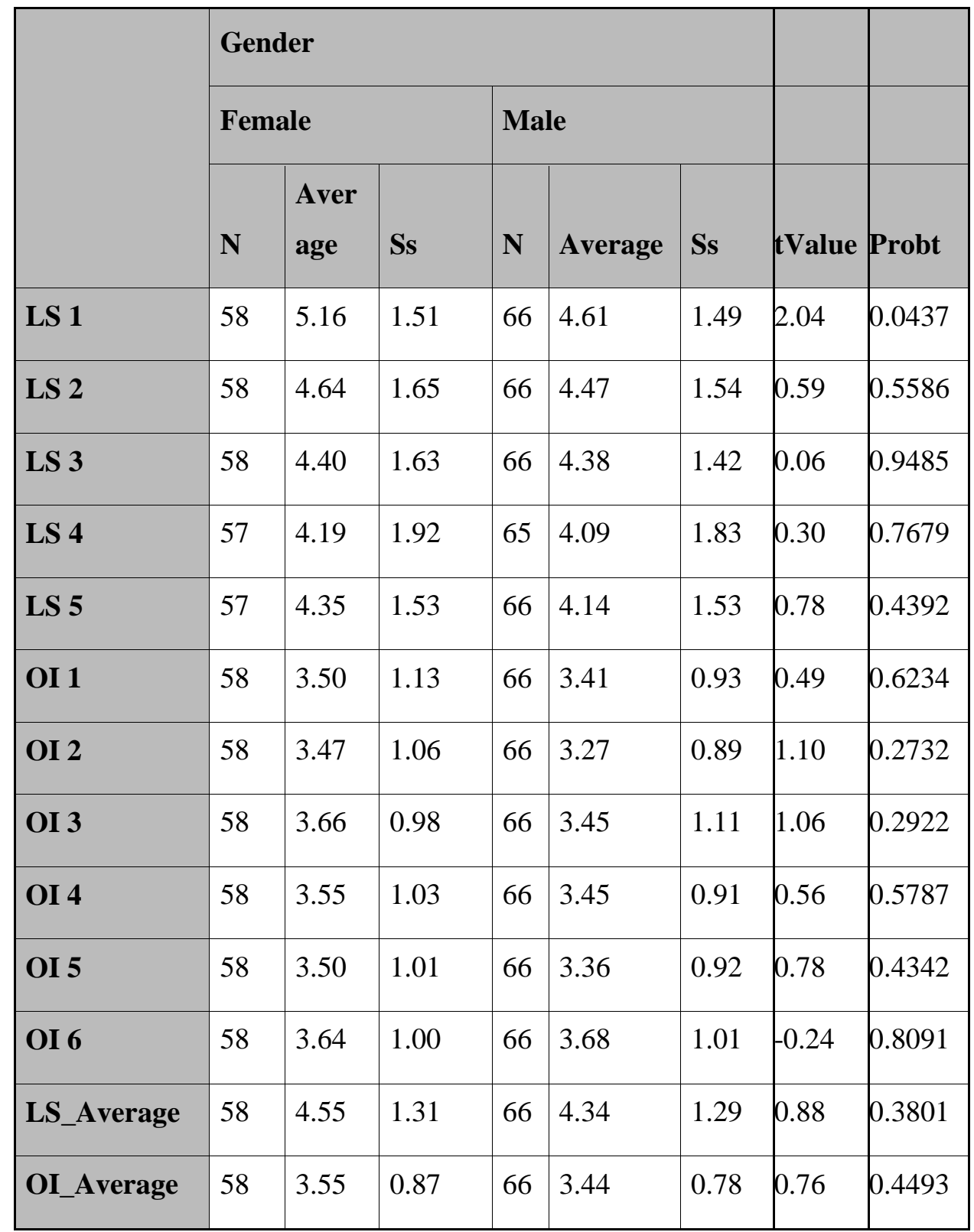

LS: Life Satisfaction

OI: Organizational Identification 


\section{Findings of the Correlation and Regression Analyses}

As a result of the correlation analysis conducted to examine the correlation between organizational identification and life satisfaction, the correlation coefficient (r) was found to be 0,350 . From a statistical point of view, there is a positive and significant relationship between the variables. $(r=350 ; p<0.0001)$.

Table2: Correlation between Life Satisfaction and Organizational

\section{Identification}

\begin{tabular}{|l|l|l|l|l|}
\hline & Mean & Std Dev & $\begin{array}{l}\text { LS_ } \\
\text { OVERALL }\end{array}$ & $\begin{array}{l}\text { OI_ } \\
\text { OVERALL }\end{array}$ \\
\hline Life Satisfaction & 4.43589 & 1.29991 & 1.00000 & $\begin{array}{l}0.35031 \\
<.0001\end{array}$ \\
\hline $\begin{array}{l}\text { Organizational } \\
\text { Identification }\end{array}$ & 3.49194 & 0.82087 & $\begin{array}{l}0.35031 \\
<.0001\end{array}$ & 1.00000 \\
\hline
\end{tabular}

As a result of the regression analysis, it was observed that organizational identification affected $12.2 \%$ of the variance in life satisfaction. The results of the analysis indicated that organizational identification was a significant predictor of life satisfaction $\left(\mathrm{R}=0,554, \mathrm{R}^{2}=0,1227 \mathrm{~F}=17.07, \mathrm{p}<0.001\right)$. According to this, it was seen that the organizational identification had a significant effect on life satisfaction $(\beta=0,55474 ; \mathrm{p}<0001)$ and explained the variance at a rate of $12.2 \%\left(\mathrm{R}^{2}=0.1227\right)$. In the light of this data, it can be suggested that organizational identification was a significant predictor of life satisfaction although not very high. It can be stated that $12 \%$ of total variance related to life satisfaction was explained by organizational identification. 
Table 3: Regression Analysis Results

\begin{tabular}{|l|l|l|}
\hline \multirow{2}{*}{ Independent Variable } & \multicolumn{2}{|l|}{ Dependent Variable } \\
\hline \multirow{4}{*}{ Organizational Identification } & \multicolumn{2}{|l|}{ Life Satisfaction } \\
\cline { 2 - 3 } & $\mathbf{B}$ & Sig \\
\cline { 2 - 3 } & 0,55474 & $<.0001$ \\
\cline { 2 - 3 } & $\mathrm{R}^{2}=0.1227$ \\
& $\mathrm{~F}=17.07$ \\
\hline
\end{tabular}

\section{DISCUSSION AND CONCLUSION}

In the study conducted on travel agency employees, a moderate positive relationship was found between organizational identification and life satisfaction. Thus, it was concluded that there was a correlation between organizational identification and life satisfaction. The findings obtained are consistent with the results in the literature.

An essential element for people to be happy and satisfied in their lives is the satisfaction they get from their jobs. People need to be happy and satisfied with their jobs to get the same amount of satisfaction from their lives. This attitude, taken in relation to business life, can affect life satisfaction over time (Karakus, 2011: 47).

As organizational identification is an important indicator of job satisfaction, the high level of organizational identification of employees will also positively contribute to life satisfaction. Therefore, job satisfaction will increase as the level of identification increases, and job satisfaction will bring along organizational success.

In this context, the study has both theoretical and methodological contributions. The employees of the travel agencies that participated in the study establish a connection between organizational identification and life satisfaction. The research indicates that the employees' organizational identification levels are not high but predict life 
satisfaction. When the literature on the topic was analyzed, it was seen that there is not much research conducted on the relationship between identification and life satisfaction despite the high number of studies on organizational identification and job satisfaction. At this point, it is believed that this original study examining the relationship between organizational identification and life satisfaction will contribute to the national literature. The findings of the study give important clues for travel agency managers. First of all, it will be beneficial for managers to focus on practices that will increase the organizational identification levels of their employees. Organizations that expect high performance from their employees should shape their work activities by considering this positive relationship and focus their attention on practices that will help enhance their employees' level of organizational identification. In this sense, organizations should try to design the working environment in a way to fulfil the expectations of employees and to pave the way for their employees to be happy in their private life as well. One of the main objectives of successful and effective management in the sector is to support and motivate employees by providing the cooperation between employee and organization.

\section{Limitations of the Study and Recommendations for Future Studies}

This study was limited to employees working in travel agencies operating in Antalya. However, the small number of the enterprises that agreed to take part in the study and the fact that the study was conducted on a limited sample group constitute the most important limitations of the study. Conducting this type of research with larger samples in different destinations by using similar scales will help to improve the issue over time. However, the inclusion of different variables that may affect life satisfaction will allow different conclusions to be made. 


\section{REFERENCES}

- Abrams, D., Ando, K. \& Hinkle, S. (1998)."Psychological Attachment to the Group: Cross-cultural Differences in Organizational Identification and Subjective Norms as Predictors of Workers' Turnover Intentions". Personality and Social Psychology Bulletin, 24 (10), 1027-1039.

- Akgündüz, Y. (2013). "Konaklama İşletmelerinde İş Doyumu, Yaşam Doyumu ve Öz Yeterlilik Arasındaki İlişkinin Analizi”. Celal Bayar Üniversitesi Sosyal Bilimler Dergisi, 11(1), 180-234.

- Asforth, B. E. \& Mael, F. A. (1989). "Social Identity Theory and Organization". The Academy of Management Review, 14(1), 20-39.

- Aşan, Ö.\& Erenler, E. (2008). "İş Tatmini ve Yaşam Tatmini İlişskisi". Süleyman Demirel Üniversitesi İktisadi ve İdari Bilimler Fakültesi Dergisi, 13 (2), 203-216.

- Boroş, S. (2007). "Organizational Identification: Theoretical and Empirical Analyses of Competing Conceptualizations". Romanian Association for Cognitive Science, 12(1), 1-27.

- Chan S. H. (2006). "Organizational Identification and Commitment ofMembers of a Human Develop Organization". Journal of Management Development, 25(3), 249-268.

- Çeçen, A. R. (2008). "Üniversite Öğrencilerinde Yaşam Doyumunu Yordamada Bireysel Bütünlük (Tutarlilik) Duygusu, Aile Bütünlük Duygusu ve Benlik Saygısı”. Eğitimde Kuram ve Uygulama, 4(1), 19-30.

- Çetin, M. \& Kinik, S. (2016). "The Reflections of Organizational Identification Built Upon Social Identity Theory on the Perception of Alienation in Higher Education". WEI International Academic Conference Proceedings, Boston, USA. 
- Çevik, N. K. \& Korkmaz, O. (2014). “Türkiye'de Yaşam Doyumu ve İş Doyumu Arasındaki İlişkinin İki Değişkenli Sıralı Probit Model Analizi”. 7(1), 126-145.

- Çivitçi, A. Topbaşoğlu, A. (2015). "Akılcı Duygusal Eğitimin Ortaokul Öğrencilerinin Yaşam Doyumları Üzerindeki Etkisi”. Ege Eğitim Dergisi, 16(1), 13-29.

- Diener, E. D., Emmons, R. A., Larsen, R. J. \& Griffin, S. (1985). “The Satisfaction with Life Scale”. Journal of Personality Assessment, 49(1), 7175.

- Dikmen, A. A. (1995). "İş Doyumu ve Yaşam Doyumu İlişkisi”. Ankara Üniversitesi SBF Dergisi, 50(03), 115-140.

- Dutton, J., Dukerich, J., \& Harquail, C. (1994). “Organizational Images and Member Identification”. Administrative Science Quarterly, 39(2), 239-263.

- Efraty, D., Sirgy J. \&Claiborne, C. B. (1991). "The Effects of Personal Alienation on Organizational Identification: A Quality of Work Life Model". Journal of Business and Psychology, 6(1), 57 - 78.

- Foote, N. N. (1951). "Identification as the Basis for A Theory of Motivation". American Sociological Review, 16(1), 14-21.

- Ghiselli, R. F., La Lopa, J. M., \& Bai, B. (2001). "Job Satisfaction, Life Satisfaction, And Turnover Intent: Among Food-Service Managers". Cornell Hospitality Quarterly, 42(2), 28-37.

- Hoyer, P. (2016). "Making Space for Ambiguity: Rethinking Organizational Identification from A Career Perspective". Scandinavian Journal of Management, 32(3), 166-177.

- Jiang, H. (2010). "The Relationship between Organizational Identification and Organizational Outcomes", International Conference on Management and Service Science, Whuna, China.

- Kale, E. (2013). "Konaklama İşletmelerinde Öz Uyumun İs Performansına Etkisi: Yasam Doyumunun Aracı Rolü”. Çanakkale On sekiz Mart Üniversitesi Yönetim Bilimleri Dergisi, 11(21), 117-134. 
- Karacabey, C.N. \&İşcan, Ö. F. (2007). “Örgütsel Özdeşleşme, Örgütsel İmaj ve Örgütsel Vatandaşlık Davranışı İlişkisi: Bir Uygulama", İktisadi ve İdari Bilimler Dergisi, 21(2), 231-241.

- Keser, A. (2005). "İş Tatmini ve Yaşam Tatmini İlişkisi: Otomotiv Sektöründe Bir Uygulama", Çalışma ve Toplum, 4, 77-96.

- Lee, C. C., Wu, C. C. \& Lee, H. M. (2009). "Factors that Influence Employees' Organizational Identity after $\mathrm{M}$ \& A: The Acquirer and Acquired Perspective", African Journal of Business Management, 3 (11), 695-704.

- Meal F.A. \& Ashforth, B. E. (1992). "Alumni and their Alma matter: A Partialtest of the Reformulated Model of Organizational Identification". Journal of Organizational Behavior 13 (2), 103-123.

- Özyer, K., Irk, E., \& Anaç, S (2015). "İş Tatmini Ve Yaşam Tatmini İlişkisinde İş Arkadaşlığının Aracılık Rolü”. C.Ü. İktisadi ve İdari Bilimler Dergisi, 16(1), 261-278.

- Riketta, M. (2005). "Organizational Identification: A Meta-analysis". Journal of Vocational Behavior, 66 (2), 358-384.

- Saldaml1, A. (2008). "Otel İşletmelerinde Bölüm Yöneticilerinin İş ve Yaşam Tatmini Belirlemeye Yönelik Bir Alan Araştırması". Marmara Üniversitesi İktisadi ve İdari Bilimler Fakültesi Dergisi, 25(2), 693-719.

- Sumner, R., Burrow, A. L. \& Patrick L. H. (2015). "Identity and Purpose as Predictors of Subjective Well-being in Emerging Adulthood". Emerging Adulthood, 3(1), 46-54.

- Şimşek, E.,\& Aktaş, H. (2014). "Örgütsel Sessizlik ile Kişilik ve Yaşam Doyumu Etkileşimi: Kamu Sektöründe Bir Araştırma”. Anadolu Üniversitesi Sosyal Bilimler Dergisi, 14(2), 121-136.

- Tavşanc1l, E. (2002). Tutumların ölçülmesi ve spss ile veri analizi. Ankara, Nobel Yayinc1lik. 
- Tokgöz, E. (2012). Örgütsel Güven, Örgütsel Özdeşleşme ve Örgütsel Vatandaşlık Davranışı Arasındaki İlişki, Yayımlanmamış Yüksek lisans Tezi, Balıkesir Üniversitesi Sosyal Bilimler Ens., Balıkesir.

- Tokgöz, E. \& Seymen, O.A. (2013). “Örgütsel Güven, Örgütsel Özdeşleşme ve Örgütsel Vatandaşlık Davranışı Arasındaki İlişki: Bir Devlet Hastanesinde Araştırma”.Öneri Dergisi, 10(39), 61-76.

- Tolman, E. C. (1943). "Identification and the Postwar World". The Journal of Abnormal and Social Psychology, 38(2), 141-148.

- Uyguç, N., Arbak, Y., Duygulu, E., \& Çıraklar, N. H. (1998). "İş ve Yaşam Doyumu Arasındaki İliş̧kinin Üç Temel Varsayım Altında İncelenmesi”. DE ÜII BF Dergisi, 13(2), 193-204.

- Van Knippenberg, D. (2000). "Work Motivation and Performance: A Social Identity Perspective". Applied Psychology: An International Review, 49(3), 357-371.

- Van Knippenberg D, \& Sleebos, E. (2006). “Organizational Identification versus Organizational Commitment: Self-definition, Social Exchange, and Job Attitude". Journal of Organizational Behavior 27 (5), 571-584.

- Yeşiltaş, M. (2012). Örgütsel Özdeşleşmenin Oluşmasında Belirleyiciler Olarak Etik Liderlik ve Etik İklim: Otel İşletmelerine Yönelik Bir Uygulama. Yayımlanmamış Doktora Tezi, Gazi Üniversitesi Sosyal Bilimler Ens. Ankara.

- Yiğit, R., Dilmaç, B. \& Deniz, M. E. (2011). "İş ve Yaşam Doyumu: Konya Emniyet Müdürlüğü Alan Araştırması”. Polis Bilimleri Dergisi, 13 (3), 118.

- Zhao, X. R., Ghiselli, R., Law, R., \& Ma, J. (2016). "Motivating Frontline Employees: Role of Job Characteristics in Work and Life Satisfaction". Journal of Hospitality and Tourism Management, 27, 27-38.

- Zhao, X. R., Qu, H., \& Ghiselli, R. (2011). "Examining the Relationship of Work-Family Conflict to Job and Life Satisfaction: A Case of Hotel Sales Managers". International Journal of Hospitality Management, 30(1), 46-54. 